Journal of Education and Vocational Research (ISSN 2221-2590)

Vol. 6, No. 4, pp. 45-58, December 2015

\title{
The Effect of Early Child Introduction to Pre-Vocational Subjects at the Primary School Level to Enhance Technological Growth in Developing Nations
}

\author{
Ohwojero Chamberlain \\ Delta State University Secondary School, Nigeria, West Africa \\ cohwojero@gmail.com
}

\begin{abstract}
Technology is the power of development in many nations economy in this $21^{\text {st }}$ century. Many developed nations in the western world have viable economy and strong technological background because of good educational foundation that was enhanced from the elementary stage of a child. Elementary education equips a child with good future background that will help to groom and prepare a child for future technological development and challenges. Nigeria as one of the developing countries in the world was used as a case study because of its poor educational background, which is the reason of this research on how to impart technological skills into children at the primary school level to enhance technological growth. To carry out this study three research questions were raised to guide the study with three hypotheses. All the primary schools in Nigeria were used as the population of the study. Questionnaire was the major instrument used for data collection. Data were analysed using mean and t-test analysis. Findings and recommendations were made to enhance the implementation of pre- vocational subjects in the developing Nations.
\end{abstract}

Keyword: History of education in Nigeria, Primary Education in Nigeria, Pre- Vocational Education in Nigeria

\section{Introduction}

Education is the most vital tool that is used in the development of a child future, education has transformed the life of man in this $21^{\text {st }}$ century by making man to be socialized and civilized within his environment and beyond. Man was able to do this because of early exposure to education from early childhood. Early education from childhood has distinct man from other classes of animals because man has been able to demonstrate skills or talents that are not common with other class of animals. Education has helped to bring fast development and transformation in the different life stages of a man starting from the early life stage of a child that is called early childhood education. Early childhood education makes a child to be focused and well developed in his or her mental ability, because a child can develop his mental reasoning by learning through play. Bodrova and Leong (1996) states that during the early stages of a child development, children learn by playing in a well developed environment that inspires them to relate with that environment. Intellectual development and skill acquisition is faster in children during playing process when they are early introduced. Children learn fast when they play and interact within the environment in which they live. Many researches carried out on early childhood education has shown that high quality child care experience support the development of social and academic skills that will facilitate children success in the school (Rebekah, Caitin, Jacqueline, and Elizabeth, 2013). From research and philosophy of a popular psychologist Jean Piaget that was carried out in children that was centred on the "Power of play" observed that children learn more efficiently, effectively and gain more knowledge through play activities. This was supported by Elkind (2008) who from his own study stated that children learn more and faster when they interact and play together. Jean Piaget theory and study was centred on the epistemology that has to do with the cognitive developmental stage in children. Kendra (2013) summarized Jean Piaget cognitive development of children in to four stages.

- The sensor motor Stage: In this stage children acquires knowledge through sensory experience and manipulation of objects.

- The pre operational Stage: During this stage children learn through pretend play, but still struggle with logic and taking the point of view of other people.

- The Concrete Operational Stage: At this stage of development in children they think more logically, but their thinking may be very rigid. Here they tend to struggle with abstract and hypothetical concepts.

- The formal operation Stage: This is the final stage of Piaget's theory which involves children increase in logic, the ability of children to use deductive reasoning and understanding of abstract ideas. 
The important thing to note about Jean Piaget theory of cognitive development in children is that development in children was not based on quantitative process, but based on information and knowledge that they add to their existing knowledge as they grow older. Jean Piaget in 1934 stated that "only education is capable of saving our societies from possible collapse whether violent or gradual" (Alberto, 2000). Education is an investment that pays at any time, investment in education has become even more paramount in the recent times, because education is the bedrock of knowledge (Amodu, 2014). To make this research more elaborate and well focused, the general history of education in Nigeria as one of the developing countries that was used as a case study will be discussed, Education at the primary school level in Nigeria and Pre-Vocational education in Nigeria will also be discussed, to enable this research achieve its set goals and objectives.

\section{Literature Review}

History of Education in Nigeria: Education as a weapon of development in any nation is defined by many authors from different perspective or view. Parankimalil (2012) described education as a systematic process through which a child or an adult acquires knowledge, experience, skills and sound attitude. Orobosa (2010) define education as the process by which an individual acquires many physical and social capabilities demanded by the society in which he or she has been born into to function. This agrees with Schofield (1982) quoting lodge that says "education is acquired through experience" experience that is acquired every day at home, in the street, farm land and schools etc. Nduka (1964) refers to education as the process of transmitting people's culture from one generation to the other. Conclusively, it can be said that education is a life-long process that helps a child to be developed in to manhood to become self-reliance and dependents, by acquiring knowledge and skills that will make him performing tasks in the workshop. Education provides the sum total of all the ways by which a child can develop his abilities, attitudes and all forms of behaviours that will make a child to be a good workman in the future.

The Nigerian National Policy on Education (1981) state that basic education covers education that is given to children between the ages of 3 to 15yrs of age, which includes pre-primary programme from the ages of 3 $5 y r s$, and nine years of formal compulsory education that consist of six years of primary education before spending three years at the Junior secondary school. After the basic education as designed by the Federal Government, at the age of 15 years, the child is expected to write a qualifying examination that will enable him or her qualify to proceed to senior Secondary School, where the child is expected to spend another 3 years before writing qualifying examination, where the child will be awarded a Certificate that qualifies him or her into tertiary institutions like colleges of education (NCE), polytechnics or Universities. Below is an Organo-gram of Educational structure of Nigeria as designed by the Federal Ministry of Education in Nigeria (Onyukwu, 2011).

Primary Education in Nigeria: Primary education in Nigeria is free and compulsory for children from the ages of 6-12yrs. Primary school education curriculum is geared toward the providing of permanent literacy, laying a sound basis for scientific, critical and reflective thinking and also equipping children with the core life skills to function effectively in the future. Under the new Universal Basic Education (UBE) system of 9-3-4 that replaced the formal Universal primary education scheme of 6-3-3-4 of Nigeria system of education were children spend six years at the primary school level. The Universal Basic Education (UBE) was introduced by President Olusegun Obasanjo on September 30th 1999 (Amanze, 2008). The Universal Basic Education (UBE) at the primary school level was designed to equip children with knowledge of knowing how to read and write, acquire social skills, technological skill, mental development, and self stability etc. There are so many challenges facing Nigerian primary school education. According to Egwu (2009) the problems facing primary school education are wide disparity between the expected school enrolment and their actual enrolment. Poor management of information has lead to conflicting statistics about the number of primary schools, one source put it as 54,434 public primary schools another source from school census put the number at 87,941 and enrolment figure of $24,422,918$. Out of which males are 13,302.202 (55\%), while female figure is 11,120,649 (45\%), which indicate gender imbalance of $83.6 \%$, (Sofowora, 2010). The above statistics revealed that there is a short fall of 10.5 million from the expected target of 34.92 million. The inability of the country not to meet the target according to late Fafunwa, was caused by financial problems, incompetent teachers, overcrowded classrooms, narrow curriculum content, high rate of drop-out and lack of quality control of children at 
primary school level (Omotayo, Ihebereme, Maduewesi, 2008). These problems has caused decline in the standard of primary school education in Nigeria. The major cause of the above problems in primary school education in Nigeria is that Nigeria as a country like every other developing nation still operates the old model type of educational system that was inherited from the colonial masters.

Presently, the management of primary school education in Nigeria is entrusted to the National primary Education Commission that performs the following functions, the body prescribes the minimum standard for primary education throughout Nigeria. Makes inquiries and gives advice to the Nigerian government on how to fund primary school education as established by the federal government. The presidential summit meeting held at Abuja in October 2012, delegates representing each state called for immediate action on how to compress the curriculum of offered subjects at all levels of basic education (Dayo, 2012). It was at this summit meeting, that recommendations were made that the number of subjects offered at the primary school level should be reduced. Summarily, it can be concluded from all the statistical data, records, observations made by different authors, over the challenges facing primary school education programme in Nigeria that primary school education has not been able to achieve its aims and objectives like it has also affect other developing nations in the world. The aim and objectives of every government of any nation is to make education free and compulsory for every child within the ages of 6-12 years to enable every child learns how to read and write, acquire skills that will be of help to them in the society in which they live like it is practice in Nigeria. Therefore primary education in most developing nations requires overhauling and reformation like it is done in Nigeria where the federal government changes educational policy from time to time to find solutions to educational problems. This study will assist every child in the developing countries to acquire good basic knowledge, mental development, stability, social skill, technological skill as they grow into adult, to face future challenges.

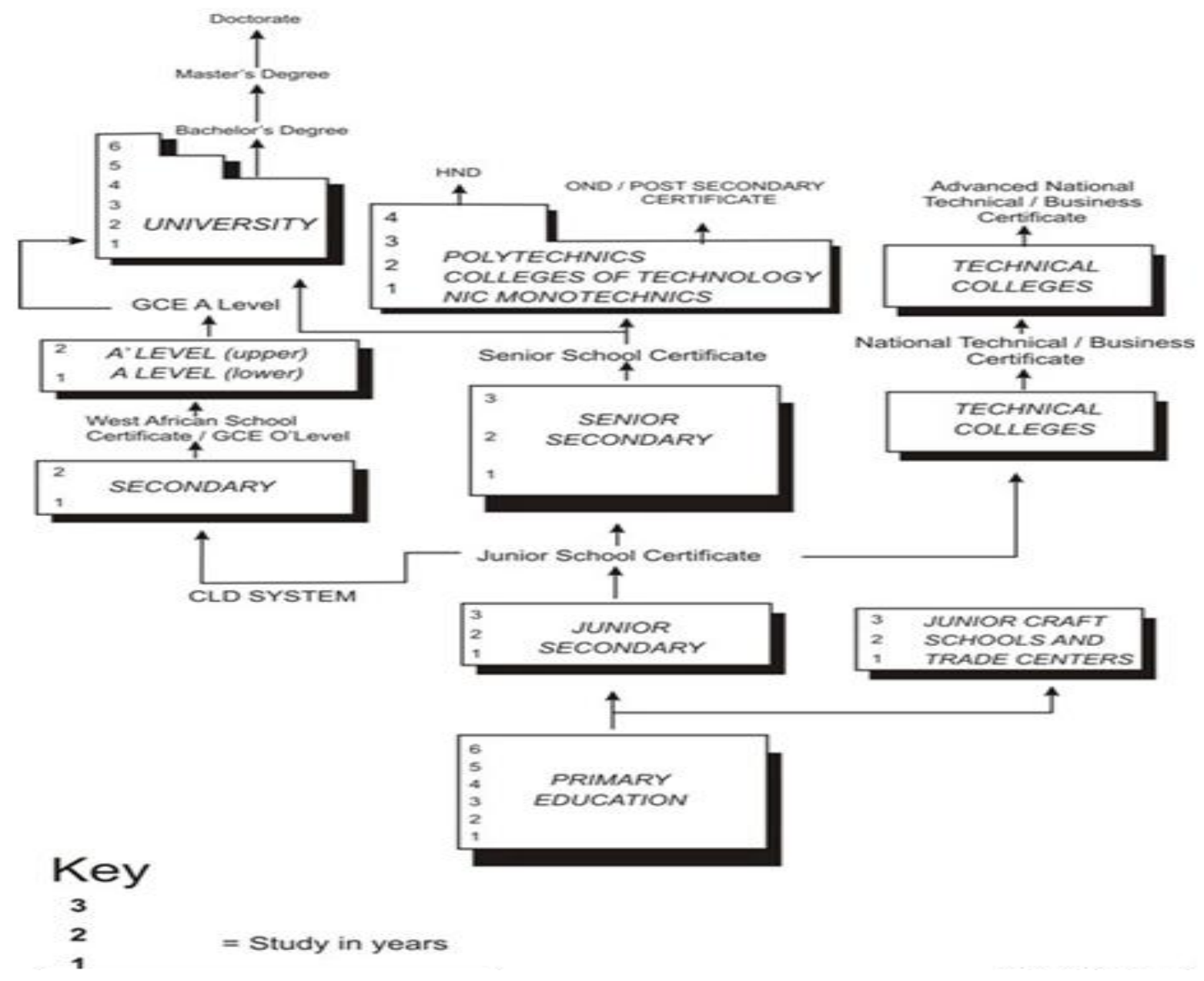


Pre- Vocational Education in Nigeria: Many authors in the past have not being able to state clearly the definition of pre-vocational education. All their definitions are centred on vocational and technical education as it applies to people from the ages of 16yrs and above. Technical and Vocational Education (TVE) has been an integral part of national development strategies of many nations, because of its impact on productivity and economic development. Despite its contributions the leaders of Nigeria have not given this aspect of education the attention required (Dike, 2009). But in a clear context; pre-vocation is the elementary stage of full vocational education, where children and youth are exposed to the acquisition of elementary skills while in school or job training for future use. Vocational and technical education has been defined by different people. Okolocha (2012) defined vocation education as an education that encompasses knowledge, skills, competencies, structural activities, abilities, capabilities and all other structural experiences acquired through on the job , that is capable of enhancing recipients opportunity for security jobs in various sector of the country. Manfred and Jennifer (2004) advocated that vocational and technical education comprises of a more organized or structured activities that aimed at providing people with the knowledge, skills and competencies necessary to perform a job. Vocational and technical education facilitates the acquisition of practical and applied skills as well as basic scientific knowledge; it is therefore a planned program of courses and learning experiences that begins with exploration of career options that supports basic academic standard, leadership and preparation for industry. Claude (2003) stated that there is ample of evidence that better qualifications and skills protect individual from unemployment. To support this statement it is very clear that an average workman in the society that lacks qualification of performing any job or does not have any good skill of carrying out any job cannot be reckoned with among his age groups in Nigerian society, because he cannot be identified for any skill.

A change in a country economical growth requires preparation of able body young people that are trained from childhood for jobs that exist in the society for the future. It is the vocational and technical education that has integral part of national development (Nuru, 2007). According to Van Ark (1992) the Dutch school system pays more attention to higher standards performance in mathematics and technical education among children from the age's 14-16yrs of age. This is to enable children at that age to develop their interest in technology and mathematics that will help to develop the mental reasoning of children at that age, also to equip them with good skill acquisitions. May (2006) observed that the neglect of vocational and technical education in the area of adequate personnel, financial support, and facilities to encourage technical and vocational education in Nigeria has robbed the nation of graduate contributing their quarter in terms of skill acquisition to the nation economy. Furthermore, Asogwa and Diogu (2007) assert that there is an urgent need for people's attention to be redirected towards self-reliance and sustainable means of livelihood that vocational and technical education can provide to the society, individuals for economic growth of the society. Developed countries in the western world like America, Britain, France, Germany, Canada etc., they are great today because of their involvement in technological reformation from the grass root brought about their greatness in vocational and technical education. Michael (2002) outlined some of the efforts of European Union member states in reforming and repositioning of vocational and technical educational programme in their countries to bring about high technological advancement. Most of the developed countries in the western world were able to bring vocational and technical education to the grass root to help build good skills into their children at their tender age in life when they are still developing. At this stage of children development school teachers can prepare children for Jobs, which are within their abilities by helping them to develop skills related to safety, personal care, time management and endurance.

Pre-vocational and technical education is built on mathematical skills that prepare children for possible vocational opportunities after high school. The mathematics skill helps to develop child mental reasoning and thinking. Another vital skill needed in the development of pre-vocational and technical education program is a motor skill that is described as gross motor skill. This skill helps children to perform tasks. Organizational skill is another vital prerequisite for a child development in pre-vocational and technical education program. This type of skill helps children to prepare for various job responsibilities regardless of the type of job they are being trained for. Example of an organizational skill is time management on a task that is being performed. A social skill is very important in the child development because it is social skill that helps to develop ones social level of interaction in any work place or environment. Social skill is an important device that helps to bring peace and orderliness in a work place. In pre-vocational and technical education children can be exposed to public interaction, making them to buy things on their own, transporting 
themselves through public means of transportation, to expose them to social interaction. It is very necessary and important to expose children undergoing pre-vocational and technical education training to safety rules in the workshop because in the workshop Children work with tools, clean workshop surrounding, move within the workshop environment. A supervised excursion of outing to visit established industries can help to reinforce safety skill in pre-vocational education, within an industrial certain. Shivani (2012) stated that prevocational and technical educational courses at the elementary stage life of children within the society helps children to identify their interest at an early stage and also able to pursue their future when they get out of school. Education contributes to better health, higher incomes and increase enrolment in the community life (Kenya Institute of Education 2012). President Barack Obama government is focused on early child education for children in America. Millions of dollars was approved to support early child education in America presently. Early child funding program in America was sponsored by the secretary of state's Arne Ducan who moved from state to state, allocating fund to states to help fund early child education program in United State of America. Among the six state that received the fund where California, Colorado, Illinois, New Mexico, Oregon and Wisconsin. The purpose of this grant was to support early child educational programme by Barack Obama administration to provide solid educational background to every child in America who are the leaders of tomorrow.

Pre-Vocational and Technical Education in Nigeria and other developing countries compared to the developed nations like America, Britain, Germany, France and some developing countries like Kenya, south Africa who showed interest in pre-vocational and technical education, Nigeria as a country cannot compare her level of technology with the western world. The technology of any country rest upon the solid foundation that is prepared for the young children that starts their educational carrier from the elementary stage of their life, because of this reason the president of America Barack Obama, despite all the technology America still see the need to invest in early child education which is the bedrock of man development and countries technological advancement. It is very important to note that early child education brings about child development in terms of skill acquisition, mental and social skills development in children at the primary school level. The early introduction to pre-vocational and technical subject in some of the developed countries in the western world gave children solid foundation in their educational background which they build on in the nearest future. Almost all the developed countries where pre-vocational and technical education is given attention that children are being exposed to the use of computers that helped to facilitate the training of a child in technological area. Hence Ohwojero (2013) stated that computer education will make an impact in the study of Automobile technology in Nigerian Secondary schools if well implemented in schools at the elementary stage of children. It therefore means that when pre- vocational subjects are introduced at the primary school level in developing nations, it will help to better the foundation of technological development in developing countries Nigeria which can also be implemented in the developing nations to enhance technological advancement.

Statement of the Problem: A quality assurance is a good mechanism that helps to evaluate the effectiveness, efficiency and appropriateness of teaching and learning process in any educational system. Quality assurance helps to evaluate children level of intelligence, skill acquisition, brain development and social skills. A good quality education has that assurance of building in to children how to develop confidence of trying to discover new things around them and how to make new discovery a reality in their life. When a child is well developed through teaching and learning process the zeal to know more will be developed. Quality assurance is seen as a holistic method of identifying and resolving educational problems to ensure improvement in educational system. Bateman (2006) states that a good quality assurance includes well defined standard of achievement, established means of responding to issues, accountability for outcomes and documented procedures for all identified processes to provide good quality education to children at the primary school to attract good enrolment of children at the primary schools. The challenges of having access to quality teaching and facilities must be resolved to provide good, sound and quality education to children at the primary school level (Birdsell, Levine and Ibrahim, 2006).

Educational system in most developing countries like Nigeria is facing a great challenge. These challenges had adverse effect on the economy and technological advancement of the countries. Hence from the past history, since 1960 Nigeria as a developing country has nothing to show in area of technology like other developing nations. Almost all the Automobiles, Computers, Electrical Appliances etc, are imported. One can hardly see 
Nigerian made technological goods like other developed countries. The poor technology advancement in Nigeria could be caused by poor educational background from the grass root, as a result of poor primary school educational background that was given to the children at the primary school level, it is clear and tested that the strength and weight of a building depend on how solid is the foundation. So any educational system that has a good policy, but not well implemented by either the government or organizations cannot stand but rather crumble like a house or building that has a poor foundation, because of the challenges facing that educational system in Nigeria. This research tends to state some research questions and hypotheses that will guide the study.

Research Questions: The study will provide answers to the following three research questions:

- How will the introduction of pre-vocational subjects at the primary school level, provide children with basic skills?

- How will the introduction of pre-vocational subjects at the primary school level, help in the development of technology?

- How will the introduction of pre-vocational subjects at the primary school level build children interest in the study of technology?

Hypotheses: Three null hypotheses were formulated and tested at 0.05 significance levels.

- There is no significant difference between children studying pre-vocational subjects at the primary school level and skills acquired.

- There is no significant difference between children studying pre-vocational subjects at the primary school level and development of technology in Nigeria.

- There is no significant difference between children studying pre-vocational subjects at the primary school level and their interest.

\section{Methodology}

The experimental research design was used in this study to gather good data. Gay, (1976) refers to experimental research as the most valid approach to solution of solving educational problems. The experimental research design method is also generally regarded as the most sophisticated research method for the testing of hypotheses. To use the experimental research design all the pupils in the selected schools were used as control group by first administering the instruments to the pupils to carry out a pre-test for two (2) months, before the teaching of the pupils for a period of six (6) months, before carrying out a post-test test as an experimental group for another two (2) months. A curriculum was design for a period of six (6) months by the researcher to teach the pupils.

Population of the study: The population of the study comprise of all the primary schools in Nigeria as a case study for the developing nations. All the primary schools were grouped in to zones 1, 2, 3, and 4 according to the four cardinal points of North, East, West and South.

Sample and Sampling Technique: Since the population of the study is large the researcher is compared to zone all the primary schools in Nigeria into four (4) zones as earlier mentioned by using intact class group. Two primary schools were selected from each of the zones making the selected primary schools used in the study to be eight (8) primary schools, with a population of not less than three hundred (300) pupils from each schools, giving a total population of two thousand four hundred $(2,400)$ pupils. All the primary schools used in the research are public government registered schools. The names of the selected schools and their zones are enlisted as follows:

Zone I: Northern part of Nigeria

\begin{tabular}{ll}
\hline Name of School & Population \\
\hline $\begin{array}{l}\text { (a) Yahaya Gusau Model Primary School, Sokoto. Dange Shuni Local Government } \\
\text { Area. Sokoto State }\end{array}$ \\
$\begin{array}{l}\text { (b) Badon Barade Model Primary School Bado, Sokoto. Wammaho Local } \\
\text { Government Area, Sokoto. }\end{array}$ & 300 \\
\hline
\end{tabular}


Zone 2: Eastern part of Nigeria

\begin{tabular}{ll}
\hline Name of School & Population \\
\hline (a) Constitution Crescent Primary School. Aba North Local Government Area. Abia State & 300 \\
(b) Omogu Primary School Ikelangwe South Local Government Area Owere-Orinta Abia & 300 \\
State. & \\
\hline
\end{tabular}

\section{Zone 3: Western part of Nigeria}

\begin{tabular}{ll}
\hline Name of School & Population \\
\hline $\begin{array}{l}\text { (a) Ibadan District Council Primary School Olu badan. Egba Local Government Area } \\
\text { Ibadan, Oyo State } \\
\text { (b) Ibadan Municipal Government Primary School Academy. Ibadan South East Local } \\
\text { Government Area, Ibadan, Oyo State. }\end{array}$ & 300 \\
\hline & \\
\hline & \\
\hline Zone 4: Southern part of Nigeria & Population \\
\hline Name of School & 300 \\
(b) Calvagina Primary School Warri. Warri South East Local Government Area,Delta State. & 300 \\
\hline
\end{tabular}

From the eight selected schools used in the study, it was observed on the enlisted chart that the number of pupils used in each school was three hundred (300) pupils. This is to easy data collection, equal representation to give accurate analysis of data.

Instrumentation: The instrument used in the study was the questionnaire; the questionnaire was designed based on the curriculum used in the study. The simple structured questionnaire was used to gather data. The questions contained in the questionnaires were asked in form of objective questions that demand simple response of yes or no considering the age and class of the children at the primary school level. Three different questionnaires were designed for the six classes, primary one to six that was used for the study based on the curriculum that was designed.

- Primary $1 \& 2$ used instrument (A) that contains questions on natural objects and manmade object.

- Primary 3\&4 used instrument (B) that contains questions on technological objects and their uses.

- Primary 5\&6 used instrument (C) that contains questions on branch of technology, products and raw materials for metal extraction. The questionnaire contains twelve (12) items that was represented in pictures and real objects and in simple question form in each of the instruments.

Reliability of the Instrument: The three instruments A, B and C was given content and construct validity to test for the internal constituency and reliability of the instruments. Sixty pupils were selected from the schools that were used for the study; the sixty pupils are not part of the sampled population used for the study. The Cronbach Alpha (? ) and the Factor Analysis was used to check for the content and construct validity of the three instruments used for the study. The Cronbach Alpha (? )was used to analyse and select quality of items in the pool of items that were designed for the construction of the instruments. The sixty students that were selected for the pilot test of the instrument were exposed to seventy items, from which a total of thirty six items were selected based on factor analysis.The average measure of all the items as contained in the instrument was determined and tested for level of significant at $p<0.05$ and the alpha (? )

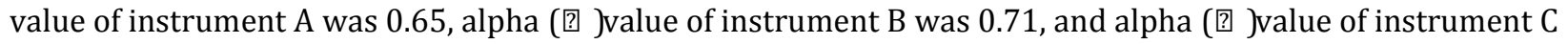
was 0.79 , the three alpha ( 3 ) values show the reliability of the three instruments. All the items that has low coefficient of alpha ( ? ) value were eliminated, to estimate the instrument for content and construct validity the factor analysis was used by first applying the descriptive statistics to find the initial communalities of all the items showing the mean and standard deviation of each items as contained in each of the instrument. The difference in the initial communalities of the items factored the items to thirty six (36) items. Eigen value of above 1 was used to select the factor of each item to get there square loading. The factor matrix of each item was rotated to get the weight of each item; the total sum of the square loading was computed to get the through Eigen value of each component or factor. This gives a total Eigen value of $68.4 \%$ for instrument $A$ that was used for Primary I \& 2, Eigen value of $67.8 \%$ for instrument B that was used for Primary 3 \& 4 , while instrument $C$ has an Eigen value of $70.0 \%$ which was used for Primary $5 \& 6$. Since the three instruments have 
an Eigen value that is above $50 \%$, therefore it means the three instruments have a content validity. Since each of the items has a factor matrix value that is between 0.49 and 0.86 therefore one can conclude that the instrument has construct validity.

Administration of Instrument: The instruments were administered directly to the pupils in their different classrooms for a period of two (2) months for pre-test excises and were used as control group. After the pretest excises the pupils were exposed to teaching for a period of four (6) months after the pre-test excises through the effort of the class teachers and they were post-tested, after the teaching for another two (2) months they were used as experimental group. Each of the instruments was administered in each school for a period of one week. Going by the population of pupils in each of the schools in the four regions that was used for the study, three hundred questionnaires (300) were administered in each of the schools. Considering the three level of pupils that was involved in the study, primary I and 2 in each of the schools were given one hundred (100) questionnaires which they responded to. Primary 3 and 4 one hundred (100) questionnaires were also administered to the pupils in each of the schools selected for the study. While in Primary 5 and 6 were also given one hundred questionnaires which they also responded to. The researcher and the teacher try to read and interpret the content of the questions contain in the questionnaire to the pupil for the purpose of understanding. The questionnaires were retrieved back from the pupils through the effort of their classroom teachers who assisted in the administering of the instruments. The retriever of the questionnaires after the administering was $100 \%$, because the pupils were well monitored and well guided. The total retrieved questionnaires were two thousand four hundred $(2,400)$. This makes the administering of the questionnaires to be $100 \%$.

Data Collection: Data were collected based on the response from the pupils that was used for the study. The collection of data was grouped into three, based on the class level of the pupils and the instrument used. The response of pupils in primary I and 2, 3 and 4, 5 and 6 in the instrument used from the eight selected are in table 1, 4 and 7, according to the research questions and the hypotheses used when carrying out the study. [

\section{Data Analysis}

Data collected from the three groups of pupils in the selected schools, primary I and 2, primary 3 and 4, primary 5 and 6 after the pre-test and post-test exercise. The data were analysed using descriptive statistic analysis to know the difference in mean and t-test to analyse the data to know the level of significant difference at 0.05 significant levels. Data were analysed based on the research questions and hypotheses stated in the study.

Research Question I: How will the introduction of pre-vocational subjects at the primary school level provide children with basic skills?

Data collected as shown in table (1) was used to analysed research question 1 and hypothesis 1 as shown on table 2 and 3.

Table 1: Raw scores of pre-test and post-test data collected from primary I and 2 respondents

\begin{tabular}{lll}
\hline S/N & PRE-TEST SCORES PRIMARY I \& 2 & POST-TEST SCORE PRIMARY I \& 2 \\
\hline 1 & 1800 & 2000 \\
2 & 1500 & 2300 \\
3 & 1400 & 1990 \\
4 & 2000 & 2390 \\
5 & 1600 & 2220 \\
6 & 1540 & 2150 \\
7 & 1900 & 2111 \\
8 & 1720 & 2335 \\
9 & 1300 & 1980 \\
10 & 1676 & 2015 \\
11 & 1100 & 2340 \\
12 & 900 & 2168 \\
\hline
\end{tabular}


Table 1 above shows the raw data scores of primary I and 2 of pupil response that was pre-test and posttested before and after their exposure to natural objects and manmade objects. To find out if the pupil were able to identify natural objects and manmade objects after the post-test.

Table 2: Data analysis of pre-test and post-test scores of research question 1 and hypothesis 1 that was based on data collected from primary I and 2

\begin{tabular}{lllll}
\hline Group & $\mathbf{N}$ & Mean & Std Deviation & Std Error Mean \\
\hline Pre-test & 12 & 1536.3333 & 322.65020 & 93.14109 \\
Post-test & 12 & 2166.5833 & 150.48253 & 43.44057 \\
\hline
\end{tabular}

From table 2 the mean value of post-test 2166.5833 is $>$ greater than the mean value of pre-test 1536.3333 . Therefore there is a significant difference in the mean value of pre-test and post-test scores of children taught using natural objects and manmade objects.

Hypothesis I ( $\left.\mathbf{H o}_{1}\right)$ : There is no significant difference between pupil studying pre-vocational subjects at the primary school level and skills acquired. In testing hypothesis I $\left(\mathrm{Ho}_{1}\right)$ the t-test analysis was used to decide the level of significant difference in table 5 .

Table 3: Summary Table of t-test Analysis of Hypothesis I

\begin{tabular}{|c|c|c|c|c|c|c|c|c|c|c|c|}
\hline \multirow{2}{*}{ Skill } & \multirow{4}{*}{$\begin{array}{l}\text { Equal } \\
\text { variance } \\
\text { assumes }\end{array}$} & \multicolumn{2}{|c|}{$\begin{array}{l}\text { Lever's Test } \\
\text { for equality } \\
\text { of variance }\end{array}$} & \multicolumn{7}{|c|}{ t-test for Equality of Means } & \multirow[t]{2}{*}{ Remark } \\
\hline & & $\mathrm{F}$ & Sig & $\mathrm{T}$ & Df & $\begin{array}{l}\text { e.g.(2- } \\
\text { tailed) }\end{array}$ & $\begin{array}{l}\text { Mean } \\
\text { Difference }\end{array}$ & $\begin{array}{l}\text { Std Error } \\
\text { Difference }\end{array}$ & $\begin{array}{l}45 \% \text { confid } \\
\text { of the Differ } \\
\text { lower }\end{array}$ & $\begin{array}{l}\text { ace Interval } \\
\text { ace } \\
\text { Upper }\end{array}$ & \\
\hline \multirow[t]{3}{*}{ Score } & & & & 6.132 & 22 & 000 & 630.25000 & 102.77327 & 843.38872 & 417.11128 & \multirow{3}{*}{$\begin{array}{l}\mathrm{Ho}_{1} \text { is } \\
\text { rejected }\end{array}$} \\
\hline & & 4.108 & 0.005 & 5.132 & 15.519 & 000 & 630.25000 & 102.77327 & 843.38872 & 417.11128 & \\
\hline & $\begin{array}{l}\text { Equal } \\
\text { variance } \\
\text { not } \\
\text { assumed }\end{array}$ & & & & & & & & & & \\
\hline
\end{tabular}

T-Cal $\rightarrow 6.132$

Critical $\rightarrow 2.09 \mathrm{df}$ at 0.05 significant level

From the values shown in table 3 it was observed that $t$-cal value of 6.132 is $>$ greater than $t$-crit. value 2.07. Therefore, there is a significant difference between children studying pre-vocational subjects at the primary school level and skills acquired. Conclusively $\mathrm{Ho}_{1}$ is rejected meaning if pre-vocational subjects are introduced at the primary school level it will make an impact on the children skill.

Research Question 2: How will the introduction of pre-vocational subjects at the primary school level help in the development of Nigerian technology?

Data collected as shown in table 2 was used to analyse research question 2 and hypotheses 2 as shown in table 5 and 6

Table 4: Raw scores of pre-test and post-test data collected from primary 3 and 4 respondents.

\begin{tabular}{lll}
\hline S/N & PRE-TEST SCORES PRIMARY 3 \& 4 & POST-TEST SCORE PRIMARY 3 \& 4 \\
\hline 1 & 1100 & 2300 \\
2 & 1500 & 2160 \\
3 & 1630 & 2320 \\
4 & 1300 & 2300 \\
5 & 1400 & 1980 \\
6 & 1700 & 2350 \\
7 & 2000 & 2360 \\
\hline
\end{tabular}




\begin{tabular}{lll}
\hline 8 & 2150 & 2380 \\
9 & 1550 & 2390 \\
10 & 1300 & 2257 \\
11 & 1420 & 2305 \\
12 & 1350 & 2275 \\
\hline
\end{tabular}

The data presented in table 4 above shows the response of pupils that were pre-tested and post-tested before and after they were exposed to the teaching of technological objects and their uses. To find out if the pupils were able to identify technological objects and differentiate between them when they were post-tested.

Table 5: Data analysis of pre-test and post-test scores of research question 2 and hypothesis 2 that was based on data collected from primary 3 and 4

\begin{tabular}{lllll}
\hline Group & N & Mean & Std. Deviation & Std Error Mean \\
\hline Pre-test & 12 & 1533.3333 & 301.12919 & 86.92851 \\
Post-test & 12 & 2281.4167 & 113.35981 & 32.72416 \\
\hline
\end{tabular}

From Table 6 the mean value of post-test 2281.4167 is $>$ greater than the mean of pre-test value 1533.3333 . Therefore there is a significant difference between the pre-test scores and post-test scores of children taught. The children did better when they were taught after their pre-test.

Hypothesis 2: There is no significant difference between the studying of pre-vocational subjects at the primary school level and technological development in Nigeria.

Table 6: Summary table of t-test analysis of hypothesis 2

\begin{tabular}{|c|c|c|c|c|c|c|c|c|c|c|c|}
\hline \multirow{2}{*}{\multicolumn{2}{|c|}{ Development }} & \multicolumn{2}{|c|}{$\begin{array}{l}\text { Lever's Test } \\
\text { for equality } \\
\text { of variance }\end{array}$} & \multicolumn{7}{|c|}{ t-test for Equality of Means } & \multirow[t]{2}{*}{ Remark } \\
\hline & & $\mathrm{F}$ & Sig & $\mathrm{t}$ & Df & $\begin{array}{l}\text { e.g.(2- } \\
\text { tailed) }\end{array}$ & $\begin{array}{l}\text { Mean } \\
\text { Difference }\end{array}$ & $\begin{array}{l}\text { Std Error } \\
\text { Difference }\end{array}$ & \multicolumn{2}{|c|}{$\begin{array}{l}45 \% \text { confidence Interval } \\
\text { of the Difference }\end{array}$} & \\
\hline Score & $\begin{array}{l}\text { Equal } \\
\text { variance } \\
\text { assumes }\end{array}$ & & & 8.154 & 22 & .000 & 748.08333 & 92.88399 & 940.71285 & 555.45372 & \multirow[b]{2}{*}{$\begin{array}{l}\mathrm{Ho}_{2} \text { is } \\
\text { rejected }\end{array}$} \\
\hline & & 6.33 & 0.017 & 8.054 & 14.519 & .000 & 748.08333 & 92.88399 & 947.22482 & 548.84185 & \\
\hline & $\begin{array}{l}\text { Equal } \\
\text { variance } \\
\text { not } \\
\text { assumed }\end{array}$ & & & & & & & & & & \\
\hline
\end{tabular}

T-Cal $\rightarrow 8.054$

T-Critical $\rightarrow 2.09 \mathrm{df}$ at 0.05 significant level

From the table value 6 the $\mathrm{t}$-cal value 8.054 is $>$ greater than $\mathrm{t}$-crit. value 2.01 . Therefore there is a significant difference between children studying pre-vocational subjects at the primary school level and the development of Nigerian technology, $\mathrm{Ho}_{2}$ is rejected. Therefore conclusively if pre-vocational subjects are introduced at the primary school level there will be development in Nigeria technology.

Research Question 3: How will the introduction of pre-vocational subjects at the primary school level increase children interest in the study of technology?

Data collected as shown in table 7 was used to analysed research question 3 and hypothesis 3 as shown in table 8 and 9. 
Table 7: Raw scores of pre-test and post-test data collected from primary 5 and 6 respondents.

\begin{tabular}{lll}
\hline S/N & Pre-test Scores of Primary $\mathbf{5}$ and $\mathbf{6}$ & Post-test scores of Primary $\mathbf{5}$ and $\mathbf{6}$ \\
\hline 1 & 750 & 2010 \\
2 & 1200 & 2390 \\
3 & 1050 & 2320 \\
4 & 600 & 2400 \\
5 & 1100 & 2115 \\
6 & 1500 & 2316 \\
7 & 1003 & 2019 \\
8 & 1270 & 2375 \\
9 & 1772 & 2280 \\
10 & 1110 & 2270 \\
11 & 1050 & 2380 \\
12 & 1431 & 2335 \\
\hline
\end{tabular}

The raw data in table 7 above shows the response of pupils that were pre-test and post-tested before and after they were exposed to the teaching of types of technology and how metal can be extracted. To find out if the pupils will be able to explain how metal is produced after the post-test exercise.

Table 8: Data analysis of pre-test and post-test scores of research question 3 and hypothesis 3 was based on data collected from primary 5 and 6

\begin{tabular}{lllll}
\hline Group & N & Mean & Std. Deviation & Std Error Mean \\
\hline Pre-test & 12 & 1153.0000 & 318.14033 & 91.83920 \\
Post-test & 12 & 2267.5000 & 140.75029 & 40.63110 \\
\hline
\end{tabular}

From table 8 above it shows that the mean value of post-test 2267.5000 is greater than $(>)$ the mean value of pre-test 1153.0000. Therefore there is a significant difference between the post-test value scores and pre-test value scores of children taught by exposing them to the use of raw materials in the production of metal to motivate pupil interest toward technology.

Hypothesis III $\left(\mathrm{Ho}_{3}\right)$ : There is no significant difference between children studying pre-vocational subjects at the primary school level and their interest.

Table 9: Summary table of t-test analysis of hypothesis 3

\begin{tabular}{|c|c|c|c|c|c|c|c|c|c|c|c|}
\hline \multirow{2}{*}{ Interes } & & \multicolumn{2}{|c|}{$\begin{array}{l}\text { Lever's Test } \\
\text { for equality } \\
\text { of variance }\end{array}$} & \multicolumn{7}{|c|}{ t-test for Equality of Means } & \multirow[t]{2}{*}{ Remark } \\
\hline & & $\mathrm{F}$ & Sig & $\mathrm{T}$ & Df & $\begin{array}{l}\text { e.g.(2- } \\
\text { tailed) }\end{array}$ & $\begin{array}{l}\text { Mean } \\
\text { Difference }\end{array}$ & $\begin{array}{l}\text { Std Error } \\
\text { Difference }\end{array}$ & $\begin{array}{l}95 \% \text { confide } \\
\text { the Differenc } \\
\text { Lower }\end{array}$ & $\begin{array}{l}\text { ece Interval of } \\
\text { e Upper }\end{array}$ & \\
\hline \multirow[t]{3}{*}{ Score } & $\begin{array}{l}\text { Equal } \\
\text { variance } \\
\text { assumes }\end{array}$ & & & 11.098 & 22 & .000 & & 100.42572 & 906.22980 & 1322.77020 & \\
\hline & & 3.917 & .060 & 11.098 & 15.147 & .000 & 1114.50000 & 100.42572 & 900.62869 & 1328.37131 & $\begin{array}{l}\mathrm{Ho}_{3} \text { is } \\
\text { rejected }\end{array}$ \\
\hline & $\begin{array}{l}\text { Equal } \\
\text { variance } \\
\text { not } \\
\text { assumed }\end{array}$ & & & & & & 1114.50000 & & & & \\
\hline
\end{tabular}

From table 9 shown above in the t-test analysis, $t$-cal value 11.098 is greater than ( $>$ ) t-crit. value 2.09. Therefore there is a significant difference between the studying of pre-vocational subjects at the primary school level and pupil interest. Conclusively $\mathrm{Ho}_{3}$ is rejected; this means the introduction of pre-vocational subject at the primary school level have effect on pupil's interest in the study of technology in Nigeria. 


\section{Findings}

In the cause of carrying out this study, the following findings were observed:

- Pupil interest was generally motivated because from the scores obtained after the post-test the mean post-test scores are higher than the pre-test scores across the three levels of pupils used for the study. Which shows that pupil showed great interest in the studying of pre-vocational subjects after the post-testing excises.

- Primary I and 2 pupil were able to identify and differentiate between natural objects and manmade objects after teaching them with objects and materials.

- Primary 3 and 4 pupil where able to identify and state the function of some technological objects after, the post-test test.

- Primary 5 and 6 pupil where able to describe the stages of carrying out the production of metal extraction using the blast furnace.

- The eight selected primary schools lacked instructional materials for the teaching of pre-vocational subjects, because the teaching aids used in this study was provided by the researcher.

- The selected schools used for this study lacked manpower that will teach the pre- vocational subjects at the primary school level.

- Pupils from the eight selected primary schools used for the study were able to demonstrate some of the skills they acquired after the post-test test.

Recommendations: Based on the findings observed in carrying out this research the following recommendations were made:

- The ministry of education of most developing nations should design a curriculum that will be built into primary schools to help build up pre-vocational skills at the early stage of children.

- Children should be encouraged or motivated to study pre-vocational subjects at the primary school level in developing nations to enhance technology.

- Government should fund and equip primary schools with instructional materials that will help to assist in the teaching of pre-vocational subject at the primary school level in most developing countries.

- Government should train teachers in the areas of pre-vocational study in most developing nations to help in the development of teacher skills.

- Children should be exposed to field trips; to help practice what they have learnt in the classroom to help motivates pupil interest in the study of pre-vocational subjects.

- The study of pre-vocational subjects at the primary school level should be made compulsory to help build technology in many developing countries.

- Children at the primary school level should be allowed to demonstrate their talents on what they can design or produced in the cause of teaching pre-vocational subjects at the primary school level.

- Scholarship grants should be given to children at the primary school level as incentives to help motivate their interest in the study of pre-vocational subjects at the primary school level.

- Community where primary schools are located should help to support the study of pre-vocational subjects by assisting primary schools with local materials to encourage the children in the study technology from the grass root in the developing countries.

\section{Conclusion}

It can be concluded from this study that based on the data gathered and analyzed, findings made about the study and recommendations. It can be concluded that if the studying of pre-vocational subjects is introduced at the primary school level curriculum in many developing nations, it will make a great impact on pupils' skill acquisition level. That will bring about good technological development in many developing nations around the world. 


\section{References}

Alberto, M. (2000). JEAN PIAGET 1896-1980. UNESCO: International Bureau of Education, xxiv, 311-327.

Amanze, O. U. (2008). Implementing Universal Basic Education (UBE) Through the strategic provision of school literary services. http://www.webpageuuidoho.edu/mbolin/amanze.htm. Retrieved $19 / 11 / 2013$.

Amodu Foundation (2014). Educational System in Nigeria: http://bffa-online.org/education.html. Retrieved $20 / 2 / 14$

Asogwa, O. \& Diogwu, G. O. (2007). In Oledinma Nwanna- Nzewunwa Challenges of the Development of Vocational Education in Nigerian Universities: Implication for National Development. University of Port Harcourt Nigeria.

Bateman, P. (2006). Quality Assurance Mechanism open distance e-learning. A paper presented at a workshop that was organized by African Virtual University Kenya. In collaboration with carregie, corporation and Information Technology and Communication Unit. Obafemi Awolowo University Ile-Ife.

Birdsell, N., Levine, R. \& Ibrahim, A. (2006). Building gender equality in urban, life. Global Urban Research Development Magazine, 2(1), 9-14.

Bodrova, E. \& Leong, D. J. (1996). Tools of the Mind: A case study of implementing the Vygotskian Approach in American Early Childhood and Primary Classrooms, International Bureau of Education.

Claude, J. B. (2003). Education and Vocational training, a mainstream solution for all groups across all number states? Impulse for European Employment Policy Impulses for Germany BMWA, Berlin.

Dayo, A. (2012). Nine-year Basic Education Curriculum takes New Shape. www.vanguard.com. Retrieved $5 / 112 / 2013$.

Dike, V. E. (2009). Definition of Education, Attitude Services www.teachi-kids-attitude-1st.com retrieved $14 / 12 / 2013$.

Egwu, S. O. (2009). Roadmap for Nigeria Educational Sector Abuja, Federal Ministry of Education Abuja.

Elkind, D. (2008). The Power of Play: Learning what comes naturally. American Journal of play: http://www.journalofplay.org Retrieved 18/1/2014.

Federal Republic of Nigeria. (1981). National Policy on Education (2nd Education) Lagos Nigerian Educational Research and Development Council Press

Gay, I. R. (1976). Educational Research Competencies for analysis and application, Ohio: Charles E. Merrill Publication Company.

Kenya Institutes of Education. (2012). contributes to better health higher incomes and increased http://www.com.ng. retrieved 8/1/2014.

Kendra, C. (2013). Piaget's Stages of Cognitive development. Background and key Concept of piaget's Theory. Psychology.about.com/od/piagets theory/a/keyconcepts.htm

Manfred, T. \& Jennifer, W. (2004). Vocational Education and Training key to the Future. Greece Colibri Ltd.

May. (2006). Oledinma Nwanna-Nzewunwa. Challenge of the Development of Vocational Education in Nigerian Universities: Implication for National Development. University of Port Harcourt Nigeria.

Michael, A. (2002). Okolocha C.C. Vocational Technical Education in Nigeria: Challenges and the way forward. Business Management Dynamics, 2, 01-08.

Nduka, A. O. (1964). Western Education and the Nigeria Cultural Background Ibadan OUP.

Nuru, A. (2007). The Relevance of National Vocational Education Qualification (NVQS) in TVE in Nigeria UNP.

Ohwojero, C. (2013). Impact of Computer Education on Students Interest and Performance in Automobile Trace in Nigeria www.iiste.org.

Okolocha, C. C. (2012). Vocational Technical Education in Nigeria: challenges and the way forward. Business Management Dynamics, 2(6), 01-08.

Omotayo, D. M., Iheberume, C. \& Maduewesi, B. U. (2008). Management of Universal Basic Education Scheme for Qualitative education in Nigeria. www.questia.com/pm.qst;Jessioni. Retrieved $18^{\text {th }}$ December, 2013.

Onyukwu, J. (2011). The Educational System of Nigeria World Education News and Reviews WENR.htm. Retrieved 28/12/2013.

Orobosa, U. (2010). Education and National Development in Nigeria Vanguard Newspaper. Retrieved $10 / 12 / 14$.

Parankimalil, J. (2012). Meaning Nature and Aims of Education. Parankimalil World press .com. 
Rebekah, L. C., Caitin, M. l., Jacqueline, S. \& Elizabeth, V. (2013). Early Education and Care Experiences and Cognitive Skill Development: A Comparative Perspective between Australian and American Children. Family matters. No 93 AIFS Journals.

Schofield, H. (1982). The philosophy of Education: An introduction. London: George Allen \& Unwin Ltd

Shivani, Y. C. (2012). Pre-Vocational training to be given to children with special needs. ARCHIVE journalism courage. Retrieved 23/1/2014.

Sofowora, O. A. (2010). Improving the Standard and Quality of Primary Education in Nigeria. International Journal for Gross Disciplinary in Education (IJCDE), 1(3).

Van-Ark, B. (1992). Vocational Education and Productivity in the Netherland and Britain National Institute Economic Review. 